\title{
Board 64: NSF S-STEM Southern Illinois Energy Scholarship Program
}

\section{Prof. Frances Harackiewicz P.E., Southern Illinois University, Carbondale}

Professor Harackiewicz is with the Department of Electrical and Computer Engineering in the College of Engineering at Southern Illinois University Carbondale. Her Ph.D. is from the University of Massachusetts Amherst. Her research and teaching interests are in electromagnetics, antennas, senior design, and experiential inter- and multi- disciplinary learning.

\section{Dr. Lizette R. Chevalier P.E., Southern Illinois University, Carbondale}

Lizette R. Chevalier is currently the Associate Dean of Academic Programs at Southern Illinois University. She is also a professor in Civil and Environmental Engineering.

\section{Mr. Omer Salih Elsanusi, Southern Illinois University Carbondale}

Omer Elsanusi earned his B.Sc. in Mechanical Engineering from University of Khartoum, Sudan in August 2009. He has been awarded the M.Sc. degree in Mechanical Engineering by Universiti Teknologi Malaysia in September 2012. He has since gained experience in buildings engineering systems. Omer is currently pursuing his Ph.D. degree in Engineering Science at Southern Illinois University Carbondale. Since his Bachelor's degree, his research interest has been towards Renewable Energy processes especially solar energy utilization and storage. He is also a research assistant in the NSF SI Energy Scholarship Program.

\section{Prof. Karen Sue Renzaglia}




\title{
NSF S-STEM Southern Illinois Energy Scholarship Program
}

\begin{abstract}
The Southern Illinois Energy Scholarships is an S-STEM program at Southern Illinois University Carbondale (SIUC) funded by the National Science Foundation. This project supports talented community-college-transfer students with demonstrated financial need and an interest in the energy field to complete a STEM degree and enter the energy workforce. This is a five-year grant supporting 43 scholars while earning baccalaureate degrees at SIUC.

Objectives of this program include providing scholarships that average $\$ 7,000$ for each of two years for each scholar, developing a mentoring and support network, and providing enrichment activities and educational experiences related to energy systems and challenges.

This paper reports activities and findings in the third year of the project that include recruitment and accomplishments of 30 scholars. Results are presented of on-going analyses of the effectiveness of program components on scholars' outcomes.
\end{abstract}

\section{Background}

The NSF Scholarships in Science, Technology, Engineering, and Mathematics Program (SSTEM) grants awards to institutions of higher education (IHE) to fund scholarships in STEM. [1] Although active duration of awards vary, five-year lengths are typical. The number of awards vary by year and award amounts vary as well. In the United States, there are about 744 active SSTEM awards at this time totaling over \$711 Million spread to every state, the District of Columbia and the U.S. Virgin Islands. [2] Scholarships can go only to those who meet the eligibility requirements which include having low-income, financial need, full-time enrollment in a STEM program (except medicine and clinical fields), citizenship/residency status, and demonstrated academic potential. [3] Financial need is defined according to the U.S. Department of Education as the cost of attendance (COA), as dictated by congress, minus expected family contribution (EFC), as calculated by the Free Application for Federal Student Aid (FAFSA) form. [4] Students are not allowed to receive aid (including loans, scholarships, and federal work-study but not including GI benefits) totaling above COA. The IHE determines the amount of financial need covered by the scholarship, but in any case, the maximum allowable scholarship per year is $\$ 10,000$. [4]

NSF S-STEM programs are not required to have a topical or major focus within STEM. For comparison, in the same year that this program began, it was found that for similarly-sized programs a focus by topic was in the minority and by major was in the majority. We considered 73 S-STEM program 17-527 awards granted in 2016 within the United States, within the NSF Division of Undergraduate Education (DUE), within the Directorate for Education and Human Resources (EHR) in the award range of $\$ 500,001$ to $\$ 1,000,000$ with standard award instrument, Abstracts indicated that only 15 of the 73 had a topical focus including energy, environment, ecological challenges, math proficiency, bioinformatics, cybersecurity, leadership and technology. Meanwhile, 51 out of the 73 had a focus on one or more particular majors within 
STEM. Science majors dominated followed by engineering and computer science. [5] In that sense, this program is somewhat unique in that it has a topical focus that is cross-cutting through many majors in science, engineering and technology.

The topical focus of this NSF S-STEM scholarship program is energy. With fossil-fuel energy sources depleting and projected human energy demands increasing, energy issues are identified among the grand engineering challenges of this $21^{\text {st }}$ century. [6] Illinois is leading the Midwest with over 119,000 clean energy jobs, [7] and thousands of jobs are expected to be added in the energy-related fields annually in the long term. [8] The 2018 report from the Intergovernmental Panel on Climate Change stresses an urgency in developing and utilizing renewable energy technologies to combat global shifts in temperature, and specifically to limit global warming to $1.5^{\circ} \mathrm{C}$ that $70-85 \%$ of electricity ought to be sourced from renewables by 2050. [9] Clearly, there is a pressing need to train skilled workers in diverse areas from green energy technologies to enhanced efficiencies of fossil fuel extraction and use. SIUC offers multiple majors and pathways to energy-related careers in the colleges of Engineering, Science, and Applied Sciences and Arts, and is positioned to meet this challenge in part through the Southern Illinois (SI) Energy Scholarship Program.

\subsection{Program Goals and Activities}

The NSF S-STEM Southern Illinois (SI) Energy Scholarship Program has the following three goals and activities toward meeting those goals:

Goal 1: Increase the number of low-income academically talented students obtaining degrees in STEM and entering the STEM workforce or graduate study (Recruit and support)

To reach this goal, high-achieving scholars from Illinois community colleges are recruited and provided with scholarships to cover tuition and fees (averaging \$7,000/year) for the two years while at SIUC and completing the baccalaureate degree. To ensure scholars advance academically and professionally, they are integrated into a mentoring and support network of staff, peers, faculty and professionals. Together they engage in a diverse set of professional development activities.

Goal 2: Improve the education of future scientists, engineers, and technicians, with a focus on academically talented low-income students (Quality Educational experiences in Energy Sciencelengineering)

Energy Scholars join a learning community through a common curriculum and faculty mentored hands-on learning experiences. Individual assistance is provided for scholars to secure internships and research opportunities that focus on collaborative interdisciplinary approaches to learning, innovation and discovery.

Goal 3: Advance understanding of the factors or curricular and co-curricular activities affecting the success of low-income students (Assess effectiveness of program elements)

Evaluation of the impact of program components on scholars' outcomes is ongoing and involves comparisons with peer groups not in the program. 


\subsection{Scholarship Eligibility}

In addition to the NSF S-STEM scholarship eligibility requirements already mentioned, the SI Energy Scholarship Program further restricts the award to those with an expressed interest in energy studies and/or an energy-related career, and a minimum GPA of 3.0 at the time of application. Applications, letters of reference, and official transcripts are reviewed before acceptance decisions are made. Students who are successfully active in the program and remain eligible are expected to receive a second year of funding as well.

\section{Results}

\subsection{GOAL ONE: Recruit and support}

\subsubsection{Recruitment:}

To date, the program has supported 30 scholars transferring from community colleges and majoring in the following nine STEM degree programs: Mechanical, Electrical, Computer and Civil Engineering, Architecture, Chemistry, Geology, Plant Biology and Agriculture Systems. Because advertising and recruitment have proven to be major challenges, our strategies have changed as the program progressed. A dedicated website was established early in the program as was an attractive brochure promoting the benefits and opportunities afforded by the scholarship. Energy scholarships were advertised by the Financial Aid office, while recruiters and academic advisors were relied upon to promote the program across the state. In an effort to increase applicants, we implemented more aggressive methods of identifying eligible students. With the assistance of recruiters and the institutional admissions office, lists of prospective transfer students were provided and the SI Energy Scholarship staff directly contacted eligible students via emails and phone calls. Collective efforts led to the recruitment of high quality students and to more than $90 \%$ of the number of participants originally projected by this date (Table 1). Efforts seem on track and comparative to another S-STEM program recently reported. In [15], the authors noted that in year 3 of the program, 26 engineering students in 2 departments had an average unmet financial need of $\$ 20 \mathrm{~K}$ and average incoming 3.69 GPA. In year 3 of this program, 30 STEM students had an average unmet financial need per year $\$ 16.7 \mathrm{~K}$ and an average incoming 3.61GPA. This is well above the national average across all majors of 3.1 GPA. [10]

In regards to diversity, currently the program is exceeding its targets of $30 \%$ women and $30 \%$ underrepresented minority participation. Of the 30 participants, 14 or $47 \%$ are females and 9 or $30 \%$ are underrepresented minorities and/or with disability. A total of 19 out of 30 or $63 \%$ of the energy scholars are underrepresented in STEM. 
Table 1 Number of scholars in first five semesters by major

\begin{tabular}{|l|c|}
\hline $\begin{array}{l}\text { Degree } \\
\text { Program }\end{array}$ & $\begin{array}{l}\text { Number } \\
\text { Scholars }\end{array}$ \\
\hline $\begin{array}{l}\text { Mechanical } \\
\text { Engineering }\end{array}$ & 11 \\
\hline $\begin{array}{l}\text { Electrical } \\
\text { Engineering }\end{array}$ & 2 \\
\hline $\begin{array}{l}\text { Computer } \\
\text { Engineering }\end{array}$ & 2 \\
\hline Civil Engineer. & 5 \\
\hline Geology & 2 \\
\hline Chemistry & 3 \\
\hline $\begin{array}{l}\text { Ag. Systems \& } \\
\text { Technology }\end{array}$ & 2 \\
\hline Architecture & 2 \\
\hline Plant Biology & 1 \\
\hline Total & 30 \\
\hline
\end{tabular}

Of the scholars that are engineering majors, seven out of twenty or $35 \%$ are female compared to only $19.8 \%$ of the national 2014 engineering Bachelor's degree share going to females. [11] In addition, seven of the twenty scholars majoring in engineering or 35\% are an underrepresented racial or ethnic minority (URM) compared to only 13.39\% of the national 2014 engineering Bachelor's degree share going to URM. [12] It is too early to know if all of these scholars will remain in engineering. Assuming the students do earn their BS in an engineering field, the statistics suggest that the scholarship program is doing a better job attracting underrepresented groups to engineering that the average national program.

2.1.2 Professional Development: To develop community, all scholars enroll in the University 301 in the first year of the program. During this one credit-hour course, scholars engaged in a wide range of enrichment activities. Career Services conducted workshops on writing resume/CV, exploring career opportunities online, preparing for career job fairs and interviewing skills. Scholars engaged in interactive sessions on responsible conduct of research, identifying and engaging with mentors, technical writing, and poster and presentation preparation.

2.1.3. Mentoring and Support Network Because of the diversity of students in the program, developing a network of mentors requires individualized attention to the needs of each student. The PIs and the graduate assistant serve as primary mentors who maintained open door policies. Scholars are also paired with faculty and staff mentors in their respective departments. During the UNIV 301 course, professionals from SIU and the community made presentations on their research and discussed energy topics with the scholars. Speakers included research faculty, the Director of the SIU Sustainability Office, a Physical Plant Engineer and a community member who runs a solar energy business. These presentations allowed students to explore career options and to hone their interests in energy science and engineering. They also served as the first exposure of scholars 
to research mentors with whom they were paired by the end of their first year in the program. Example titles and disciplines of presenters are found in Table 2.

\section{Table 2 University 301 Guest Speaker Presentations}

\begin{tabular}{|l|l|}
\hline Unit & Title \\
\hline $\begin{array}{l}\text { Advanced Coal and } \\
\text { Center SIUC }\end{array}$ & Energy and Fuel Resources \\
\hline Physical plant & Campus energy management \\
\hline $\begin{array}{l}\text { Mechanical } \\
\text { Engineering }\end{array}$ & Energy efficient cost effective passive solar house \\
\hline $\begin{array}{l}\text { Mechanical } \\
\text { Engineering }\end{array}$ & Preparing for a carbon constrained economy \\
\hline $\begin{array}{l}\text { Architecture studies } \\
\text { networks/driverless cars \& connections with other } \\
\text { modes and the built environment }\end{array}$ \\
\hline Architecture studies & $\begin{array}{l}\text { Occupancy estimation in smart building using hybrid } \\
\text { CO2/light wireless sensor network }\end{array}$ \\
\hline Electrical Engineering & $\begin{array}{l}\text { A smart IoT prototype for accurate people-counting } \\
\text { toward energy efficient buildings }\end{array}$ \\
\hline Electrical Engineering & Power consumption in VLSI circuits \\
\hline Computer Engineering & Energy, security and quality-of-experience \\
\hline Plant Biology & $\begin{array}{l}\text { Establishing plant species on constructed fen peatlands } \\
\text { for oil sands mine reclamation }\end{array}$ \\
\hline Sustainability office & Energy and sustainability \\
\hline $\begin{array}{l}\text { Advanced Energy } \\
\text { Solutions Inc. }\end{array}$ & \begin{tabular}{l} 
Solar energy business enterprise \\
\hline
\end{tabular}
\end{tabular}

2.2. GOAL TWO: Quality educational experiences in energy science/engineering

During the first year University 301 course, scholars discussed their interests in energy related areas, and participated in hands-on learning experiments. Students were required to view or read foundational information of energy systems prior to class meetings. Class interactions solidified their knowledge through discussion and debate about energy topics and challenges.

2.2.1 Educational Activities. To put their knowledge into practice, scholars conducted hands-on learning activities that include the following.

- Build a bicycle generator: Attachment of a 24 VDC generator to a bicycle coupled with three different light bulbs to demonstrate energy needed to operate these bulbs and investigate their efficiencies using thermal imaging and light intensity measurement.

- Print a 3D Stirling Engine: An assembly of 3d printed parts into a solar/other heat sources powered Stirling engine.

- Construct a simple solar thermal collector. 
- Build a solar photovoltaic module: A combination of Photovoltaic cells, a battery and an inverter for testing and measurements purposes.

- Develop a pedaling charging station, and solar race cars.

Scholars prepared informational posters on energy topics that were presented in class and they displayed their posters at the Annual SIU Undergraduate Research Forum. Topics include: Solid Electrolyte in Lithium Ion Batteries, Solar Photovoltaic Systems, Green Walls and Architecture, Solar Power Towers, Oxidative Hydrothermal Dissolution, The Stirling Engine, Wind Energy, Hydroelectric Power, The Fuel Cell, Energy Efficient Lighting Solutions, Off-grid living, Off-grid Architecture, Energy from Biomass.

To provide experience writing a grant proposal, scholars worked in teams to prepare and submit a proposal to fund a Green Fund project through the SIU Sustainability Office. The competitive program supports projects that improve the sustainability of the campus and reduce the energy and water consumption. Energy scholars submitted 12 proposals and were awarded four grants (Table 3).

Table 3 Titles of Green-Fund Proposals submitted by Energy Scholars

\begin{tabular}{|l|l|}
\hline Cohort & Green fund proposal title \\
\hline \multirow{5}{*}{1} & Solar Charging Station for Engineering Courtyard \\
\cline { 2 - 2 } & Stadium Lighting Conversion \\
\cline { 2 - 2 } & $\begin{array}{l}\text { Occupancy Motion Sensing Lights in Computer Lab } \\
\text { (Awarded) }\end{array}$ \\
\cline { 2 - 2 } & Engineering Building Bottle Filling Stations (Awarded) \\
\cline { 2 - 3 } & Parking Occupancy \\
\hline \multirow{5}{*}{2} & Parkinson Hall Room 202 Window UV Films (Awarded) \\
\cline { 2 - 2 } & Bicycle Share at Southern Illinois University Carbondale \\
\cline { 2 - 2 } & Lincoln Drive bike lanes (Awarded) \\
\cline { 2 - 2 } & Double-sided printer \\
\cline { 2 - 2 } & Efficient Lot Spots \\
\cline { 2 - 2 } & Update Saluki Stadium Lighting \\
\cline { 2 - 2 } & $\begin{array}{l}\text { Erection of an Energy Efficient Guest House/Home } \\
\text { Technology Testing Bed }\end{array}$ \\
\hline
\end{tabular}

Students were assisted in identifying a research or design mentor in their field and selecting the second year project. Moreover, Scholars are assisted in identifying and applying for summer internships and spring break externships. 
2.2.2 Senior Year Projects: In their second year, scholars conduct a two - credit hour energy focused project of their choice. They are asked to present their findings both in written technical reports and verbally to an audience of their colleagues and mentors. Table 4 lists current and completed projects.

Table 4 Example Junior and Senior Projects of Energy Scholars

\begin{tabular}{|l|l|}
\hline Discipline & Title \\
\hline Mechanical Engineering & $\begin{array}{l}\text { Solar Powered Water Purifier with Aerobic Compost Heat } \\
\text { Exchanger }\end{array}$ \\
\hline $\begin{array}{l}\text { Civil and Environmental } \\
\text { Engineering }\end{array}$ & $\begin{array}{l}\text { Optimization of the Hydrothermal Liquefaction process using } \\
\mathrm{K}_{2} \mathrm{CO}_{3} \text { as the Catalyst for Pretreated Bagasse }\end{array}$ \\
\hline Mechanical Engineering & Energy Modeling of Southern Illinois University Carbondale \\
\hline $\begin{array}{l}\text { Electrical Engineering and } \\
\text { Computer Engineering }\end{array}$ & $\begin{array}{l}\text { Smart Sensor Array and Neural Network Program for Accurate } \\
\text { Occupancy Counting }\end{array}$ \\
\hline Computer Engineering & Power Consumption Simulator \\
\hline Plant Biology & $\begin{array}{l}\text { Tolerance to sodium and utility of Carex aquatilis in reclaiming } \\
\text { oil sand sites in Canada }\end{array}$ \\
\hline Mechanical Engineering & $\begin{array}{l}\text { Energy Audit of the Student Services Building (SSB) } \\
\text { Purpose and Approach }\end{array}$ \\
\hline Geology & $\begin{array}{l}\text { Mineralogy and geochemistry of the floor rocks adjacent to dike } \\
\text { intrusions in a Southern Illinois Coal Mine }\end{array}$ \\
\hline
\end{tabular}

\subsubsection{Internships and Externships}

One outcome of this program is to assist and encourage scholars to pursue internships, externships, and REUs while still in college and to advise them about their career choices after graduation whether it is industrial full time job or pursuing a higher degree in graduate schools. See Table below for internships and externships.

Table 5: Summer Internships or Research Experience, and Externships

\begin{tabular}{|c|l|l|}
\hline \# of scholars & Position & Institution \\
\hline 3 & Internship & University \\
\hline 1 & Externship & Utility \\
\hline 2 & Internship & Company/Utility \\
\hline
\end{tabular}

2.3 GOAL THREE: Assess effectiveness of program elements

2.3.1 Retention and Placement after Graduation

The high percentage of scholars who remained as students at SIU suggests that our recruitment activities were successful in identifying strong participants in our program. Although it varies based on gender, ethnicity, background and socioeconomic class, the baccalaureate degree attainment for community college transfer students hovers around 60\%, [13]. This program seems to be doing significantly better, although as it is in progress, it is too early to know for sure. See Table below for retention and placement of scholars in this program. 
Table 6 Retention of Scholars

\begin{tabular}{|l|l|l|}
\hline Scholar status currently or upon leaving program & $\begin{array}{l}\text { Number of } \\
\text { Scholars }\end{array}$ & $\begin{array}{l}\text { Percent of } \\
\text { Scholars }\end{array}$ \\
\hline Left program (reasons vary from financial, academic, or personal) & 6 & $20 \%$ \\
\hline On course to complete the baccalaureate & 17 & $57 \%$ \\
\hline Graduated in excellent standing & 7 & $23 \%$ \\
\hline Total supported in program & 30 & $100 \%$ \\
\hline
\end{tabular}

Scholars who graduated while in the program, did so in excellent standing. Of these, most are in energy-related positions within the workforce or graduate school.

\subsubsection{GPA}

The program longitudinally follows both the Energy Scholars and a peer comparison group semester by semester collecting grade point average (GPA) for each. For each semester, each scholar's $10^{\text {th }}$-day GPA was compared to a peer $10^{\text {th }}$-day GPA. The peer GPA is calculated from the average GPA of all students of the same major, same gender, and same URM or non-URM group. Results show that for each semester, the scholars on average are doing better than their peer group. Part of this may be due to the eligibility requirement for scholars to maintain a 3.0 GPA. However, scholars who fall below a 3.0 GPA are allowed to stay in the program for an additional semester to try to bring up that GPA. So, the eligibility requirement may not be the only cause for the higher GPAs among the scholars compared to their peers. When looking at the number of scholars with GPA above the GPA of their comparison group the percentage is quite good (70\%$92 \%$ each semester).

\subsubsection{Student surveys}

An assessment on the effectiveness of the different activities reveals that scholars are satisfied with program elements (See Table below). Tours of facilities such as the Automotive Technology Center and solar building across the region were particularly well received by scholars (4.6), as were the presentations of professionals and researchers (4.2) Interactive sessions on RCR (4.4) and $\mathrm{CV} /$ Resume development (4.2) were viewed as valuable by scholars. 
Table 7: Scholars' Assessment of Enrichment Activities

\begin{tabular}{|l|l|}
\hline Activity (1=very dissatisfied to 5 = very satisfied & \\
\hline Energy Education Videos & 3.9 \\
\hline Responsible Conduct of Research/ Ethics & 4.4 \\
\hline CV and Resume Developing & 4.2 \\
\hline $\begin{array}{l}\text { Tours (Solar buildings solar business, Technology } \\
\text { Center, power plant, green roof) }\end{array}$ & 4.6 \\
\hline Career Services - Interviewing & 3.7 \\
\hline Guest Speakers & 4.2 \\
\hline Hands-On-Activities & 3.9 \\
\hline Green Fund Proposals & 3.7 \\
\hline Poster Development & 3.8 \\
\hline Meetings with Mentor & 4.0 \\
\hline Project Planning & 3.0 \\
\hline Research/ Project Activities & 4.0 \\
\hline Technical Writing & 3.3 \\
\hline Professional Presentation & 3.7 \\
\hline Mentoring New Scholars & 3.0 \\
\hline
\end{tabular}

Although students are most satisfied when being given tours of energy businesses and buildings, they have yet to be asked to make the connection as to which component has helped them achieve most. The PIs are developing two more assessment surveys: one to be given to the scholars as well as to their peer group, and another to be given to the scholars after they have had time in their positions achieved after receiving their bachelor's degree. Among other things, the PIs expect to investigate sense of belonging within their majors using the questions from [14]. The program has an outside evaluator who has suggested that the program's most successful element is that the gathering for energy activities gives the students a sense of belonging or rather of people rooting for them. He has suggested that this is even perhaps more important than the particular confidence scholars may gain from contributing to energy activities on campus.

\section{Discussion}

Two unexpectedly challenging elements of the program were recruitment of transfer students into the program, and scholars still working hours at transitional jobs while being enrolled fulltime in demanding STEM majors.

\subsection{Recruitment}

In [15], the program found recruiting transfer students to be more difficult than expected. In this current S-STEM program, this was found to be the case as well. The scholarship program was not included in the university's general application. The SI Energy program was fortunate to have both scholars and university professionals active in recruiting. Scholars would ask for flyers to help them recruit other applicants when for example visiting their community colleges. College recruiters and advisers were regularly apprised of the status of applications, and 
provided with advertising materials that they shared at both in-person and electronic venues. Still, more efforts had to be spent in recruiting than was originally planned, including as in [15] contacting recently accepted transfer students.

\subsection{Hours students are working}

According to NSF "The scholarships awarded are expected to reduce the need for students to work during the academic year." [4] In [15], one recently concluded five-year S-STEM program suggests the need for students to work was eliminated completely, other than work inside the department. It was noted that whether or not the program increased the number of graduates was not clear, but it was clear the scholars were able to contribute to the department more (by being present, engaging with other students, and helping to organize events) because the scholarship support meant they did not have to work outside of their department. In this current S-STEM program, this was not found to be the case, even when students were given as much money as their financial need and the NSF requirements would allow, many scholars worked outside of their departments. Of the ones reported, over $70 \%$ had financial need over the maximum allowable scholarship amount of $\$ 10,000$ per year, and over $50 \%$ worked while being a full-time student.

Nationally, the number of hours that undergraduate students are working are increasing. [16] In [16], it is reported that while $70 \%$ of undergraduates work, as has been the case for three decades, what is new is that now students are working more hours while enrolled full-time. The SI Energy program had 2 out of 3 scholars working while being a full-time student. Not all the scholars in this program reported their hours, which may have skewed the averages, because some known to have family businesses or otherwise work long hours were among those who didn't report a number. Still, most did report hours, and were able to work less than this national average. See Table below.

\section{Table 8 Working hours of full-time students}

\begin{tabular}{|l|l|l|}
\hline $\begin{array}{l}\text { Undergraduates enrolled full-time and } \\
\text { working on average each semester }\end{array}$ & SI Energy Scholar & $\begin{array}{l}\text { National average } \\
{[16]}\end{array}$ \\
\hline 5 hours/week or more & $66.7 \%$ & $70 \%$ \\
\hline$\geq 30$ hours/week & $0 \%$ & $40 \%$ \\
\hline Full time & $0 \%$ & $25 \%$ \\
\hline
\end{tabular}

The program is assessing the number of hours the students work, their GPA, and their semester funding deficit defined as COA minus EFC minus scholarships awarded. Albeit with high unaccounted variance, a preliminary trend seems to be that the number of hours worked at other than major-related research per semester correlates with lower GPA.

Interestingly, there seems to be little to no correlation between the average number of hours a scholar worked each semester, and average dollar amount of deficit the scholar had each semester. The deficit was defined as the COA minus EFC minus scholarship/grant awarded. 


\section{Conclusion}

Now in its third year, the SI Energy Scholarship program has accepted 30 scholars of its proposed 43 in five years. Attraction of the program to females and URM has been good. Two research questions are being addressed: 1) Do the scholars achieve academically and professionally at a higher level than non-participants? 2) What program elements do the scholars identify as important in these academic achievements? GPA and graduation rates are on track for \#1 being answered affirmatively. So far, for addressing program elements in \#2, students are most satisfied when being given tours of energy businesses and buildings, and surveys are being developed to address the question thoroughly.

\section{Acknowledgement of Support}

This material is based upon work supported by the National Science Foundation under Grant No. 1565068.

\section{Disclaimer}

Any opinions, findings, and conclusions or recommendations expressed in this material are those of the author(s) and do not necessarily reflect the views of the National Science Foundation.

\section{References}

[1] National Science Foundation, "NSF Scholarships in Science, Technology, Engineering, and Mathematics Program | NSF - National Science Foundation," 2018. [Online]. Available: https://www.nsf.gov/funding/pgm_summ.jsp?pims_id=5257. [Accessed 2018].

[2] National Science Foundation, "NSF - NSF Scholarships in Science, Technology, Engineering, and Mathematics Active Awards | NSF - National Science Foundation," 2018. [Online]. Available:

https://www.nsf.gov/awards/award_visualization.jsp?org=NSF\&pims_id=5257\&ProgEleC ode $=1536 \&$ from $=$ fund\#. [Accessed 2018].

[3] National Science Foundation, "NSF Scholarships in Science, Technology, Engineering, and Mathematics (S-STEM) nsf16540) | NSF - National Science Foundation," 2016. [Online]. Available: https://nsf.gov/pubs/2016/nsf16540/nsf16540.htm. [Accessed 2018].

[4] NSF, "NSF Scholarships in Science, Technology, Engineering, and Mathematics (SSTEM) (nsf17527) | NSF National Science Foundation," 2016. [Online]. Available: https://www.nsf.gov/pubs/2017/nsf17527/nsf17527.pdf. [Accessed 2018].

[5] NSF, "NSF Award Search: Advanced Search Results.," 2018. [Online]. Available: https://www.nsf.gov/awardsearch/advancedSearchResult?ProgEleCode=1536\&BooleanEle ment=Any\&BooleanRef=Any\&ActiveAwards=true\&\#results. [Accessed 2018]. 
[6] National Academy of Sciences on behalf of National Academy of Engineering, "Grand Challenges - 14 Grand Challenges for Engineering," 2018. [Online]. Available: http://www.engineeringchallenges.org/challenges.aspx. [Accessed 2018].

[7] Clean Energy Trust (CET), "Clean Jobs Midwest," 2018. [Online]. Available: https://www.cleanjobsmidwest.com/state/illinois. [Accessed 2018].

[8] Illinois Department of Employment Security, "Employment Projections," 2018. [Online]. Available: http://www.ides.illinois.gov/LMI/Pages/Employment_Projections.aspx. [Accessed 2018].

[9] Intergovernmental Panel on Climate Change, "IPCC - SR15," 2018. [Online]. Available: http://report.ipcc.ch/sr15/pdf/sr15_spm_final.pdf. [Accessed 2018].

[10] S. L. |. PrepScholar, "What's the Average College GPA? By Major?," 4 January 2018. [Online]. Available: https://blog.prepscholar.com/average-college-gpa-by-major. [Accessed 2018].

[11] National Science Foundation National Center for Science and Engineering Statistics (NCSES), "Engineering - Field of degree: Women - nsf.gov - Women, Minorities, and Persons with Disabilities in Science and Engineering - NCSES - US National Science Foundation (NSF)," [Online]. Available: https://www.nsf.gov/statistics/2017/nsf17310/digest/fod-women/engineering.cfm.

[12] National Science Foundation National Center for Science and Engineering Statistics (NCSES), "Field of degree: Minorities - nsf.gov - Women, Minorities, and Persons with Disabilities in Science and Engineering - NCSES - US National Science Foundation (NSF)," [Online]. Available: https://www.nsf.gov/statistics/2017/nsf17310/digest/fodminorities/. [Accessed 2018].

[13] X. Wang, "Baccalaureate Attainment and College Persistence of Community College Transfer Students at Four-Year Institutions," Research in Higher Education, vol. 50, no. 6, pp. 570-588, 2009.

[14] T. C. D. a. N. Dasgupta, "Female peer mentors early in college increase women's positive academic experiences and retention in engineering," $P N A S$, vol. 114, no. 23, pp. 59645969, 2017.

[15] A. Miguel, "ECE Scholars: NSF S-STEM Grant," in 2018 ASEE Annual Conference \& Exposition, Salt Lake City, Utah, 2018.

[16] E. Deruy, "At Universities, More Students Are Working Full-Time," 25 October 2015. [Online]. Available: https://www.theatlantic.com/politics/archive/2015/10/at-universitiesmore-students-are-working-full-time/433245/. [Accessed 2018]. 
[17] L. S. M. R. S. P. B. Ning Fang, "An S-STEM Project for Improving Undergraduate Engineering Education," in 2018 ASEE Annual Conference \& Exposition, Salt Lake City, UT, 2018. 